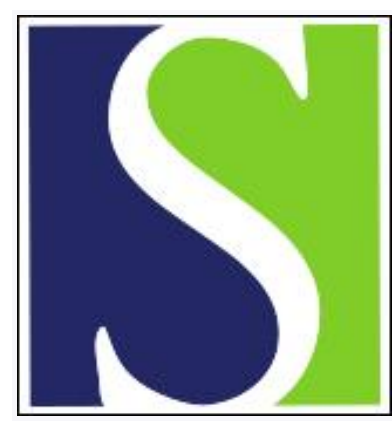

Scand J Work Environ Health 1995;21(6):427-434

https://doi.org/10.5271/sjweh.58

Issue date: Dec 1995

Musculoskeletal symptoms among sewing machine operators

by Schibye B, Skov T, Ekner D, Christiansen JU, Sjøgaard G

The following articles refer to this text: 2001;27(4):268-278;

2004;30(5):390-398; 2006;32(4):285-293

Key terms: exposure-response relationship; follow-up study; longitudinal study; neck symptom; questionnaire; repetitive work; shoulder symptom

This article in PubMed: www.ncbi.nlm.nih.gov/pubmed/8824748 


\title{
Musculoskeletal symptoms among sewing machine operators
}

\author{
by Bente Schibye, PhD, ${ }^{1}$ Torsten Skov, PhD, ${ }^{1}$ Dorte Ekner, MLT, ${ }^{1}$ Jakob U Christiansen MSc, ${ }^{2}$ \\ Gisela Sjøgaard, DrMedSc ${ }^{1}$
}

Schibye B, Skov T, Ekner D, Christiansen JU, Sjøgaard G. Musculoskeletal symptoms among sewing machine
operators. Scand J Work Environ Health 1995;21:427-34.

objectives A longitudinal study was conducted to describe the prevalences and development of musculoskeletal symptoms among sewing machine operators in relation to age and exposure and among former sewing machine operators who changed exposure by changing occupation.

Methods Musculoskeletal symptoms were assessed among 327 sewing machine operators in 1985 with the use of the standardized Nordic questionnaire. A follow-up study in 1991 showed that approximately one-third was still working as a sewing machine operator, one-third had changed occupation, and the rest were out of employment. The exposure was assessed by a questionnaire regarding the type of machine being operated, work organization, workplace design, units produced per day, and payment system.

Results High prevalences of musculoskeletal symptoms of the neck and shoulders were found, with some associations to exposure variables such as efficiency. Initially symptom-free sewing machine operators were not at a higher risk of developing symptoms when they continued sewing during the six-year follow-up when compared with those who changed to other employment. However, symptomatic sewing machine operators who quit sewing were much more likely to be relieved of their symptoms than were symptomatic operators who continued sewing, odds ratio 3.26 [95\% confidence interval $(95 \% \mathrm{CI}) 1.38-7.72$ ] for 12-month symptoms and odds ratio 3.90 (95\% CI 1.28-11.90) for 7-day symptoms. This trend also applied to long-lasting symptoms. Conclusions The results demonstrate that, for many sewing machine operators, neck and shoulder symptoms are reversible and may be influenced by reallocation to other worktasks.

Key terms exposure-response relationship, follow-up study, longitudinal study, neck and shoulder symptoms, questionnaire, repetitive work.

Musculoskeletal disorders in the neck and shoulder region are frequent among workers performing monotonous, highly repetitive, and high-speed precision tasks $(1-7)$. Numerous cross-sectional epidemiologic studies have identified sewing machine operators, office workers with visual display units (VDU operators), meat cutters, assembly-line workers, and the like as high-risk groups for developing musculoskeletal disorders in the neck and shoulders $(7,8)$, and preventive strategies are needed $(9-12)$. Risk factors such as static postures, repetitive arm movements, and lack of rest have been focused upon $(8,11,13)$. However, our knowledge is limited regarding the effect of exposure time for the individual worker since longitudinal epidemiologic studies are rare $(14-18)$. This is especially true for prolonged exposure time (ie, exposure for many years). Furthermore, only limited information exists regarding the development of chronic neck and shoulder symptoms among workers performing repetitive work $(16,17)$. The purpose of the present study was to describe musculoskeletal symptoms among sewing machine operators in relation to various exposure variables and to evaluate the development and disappearance of musculoskeletal symptoms among sewing machine operators over a sixyear period in relation to age, exposure time, and employment status. Finally, the causes for leaving this work were analyzed.

\section{Subjects and methods}

In April 1985 a cross-sectional questionnaire survey was conducted among Danish sewing machine operators (19).

1 National Institute of Occupational Health, Copenhagen, Denmark.

2 Danish Work Environment Service, Copenhagen, Denmark.

Reprint requests to: Dr B Schibye, National Institute of Occupational Health, Lers $\emptyset$ Parkallé 105, DK-2100 Copenhagen, Denmark. 
Nine factories representing different technology levels were selected. At the factories, 327 sewing machine operators were employed. Among them, 306 (94\%) answered a self-administered questionnaire. Three sewing machine operators with less than one month of employment were excluded. All the sewing machine operators were women. Their mean age was 31 (range 17-64) years, their mean height was 166 (range $151-189) \mathrm{cm}$, and their mean weight was 62 (range $44-100$ ) $\mathrm{kg}$. The mean employment time as a sewing machine operator was 6.5 (range $0.1-46.0$ ) years.

In April 1991 the home addresses of 279 of the 303 workers were traced, and $241(86 \%)$ responded to the same questionnaire. The questionnaire was extended with questions regarding present occupation and, in case the job did not involve operating a sewing machine, the reasons for leaving the job. Around one-third, 77 workers, still operated a sewing machine. Among the remaining, who were no longer sewing machine operators, 82 workers had another job (ie, as shop assistant or within the health care or fishing industry). This group is re-

Table 1. Distribution of the different exposure variables in 1985 and 1991. The percentages for those 77 sewing machine operators in 1985 who were still operators in 1991 corresponded closely with those for the total group of 303 .

\begin{tabular}{|c|c|c|}
\hline \multirow[t]{2}{*}{ Variable } & \multicolumn{2}{|c|}{ Percentage } \\
\hline & $\begin{array}{c}1985 \\
(N=303)\end{array}$ & $\begin{array}{c}1991 \\
(\mathrm{~N}=77)\end{array}$ \\
\hline \multicolumn{3}{|l|}{ Technology level } \\
\hline $\begin{array}{l}\text { Low } \\
\text { Medium } \\
\text { High }\end{array}$ & $\begin{array}{l}27 \\
50 \\
23\end{array}$ & $\begin{array}{l}. . \\
. .\end{array}$ \\
\hline Full-time employment & 78 & 67 \\
\hline \multicolumn{3}{|l|}{ Payment system } \\
\hline $\begin{array}{l}\text { Paid by the unit } \\
\text { Time wages }\end{array}$ & $\begin{array}{l}84 \\
16\end{array}$ & $\begin{array}{l}86 \\
14\end{array}$ \\
\hline \multicolumn{3}{|l|}{ Efficiency } \\
\hline $\begin{array}{l}<100 \\
100-125 \\
>125\end{array}$ & $\begin{array}{l}14 \\
42 \\
44\end{array}$ & $\begin{array}{l}11 \\
54 \\
35\end{array}$ \\
\hline \multicolumn{3}{|c|}{ Machine type most frequent operated } \\
\hline $\begin{array}{l}\text { Lockstitcher } \\
\text { Overlocker } \\
\text { Automatic sewing units } \\
\text { Others }\end{array}$ & $\begin{array}{l}36 \\
24 \\
15 \\
25\end{array}$ & $\begin{array}{r}34 \\
43 \\
4 \\
19\end{array}$ \\
\hline \multicolumn{3}{|c|}{ Number of machines operated } \\
\hline $\begin{array}{l}\text { One only } \\
\text { More than one }\end{array}$ & $\begin{array}{l}78 \\
22\end{array}$ & $\begin{array}{l}78 \\
22\end{array}$ \\
\hline \multicolumn{3}{|c|}{ Leaving machine for collecting own materials } \\
\hline $\begin{array}{l}\text { Yes } \\
\text { No }\end{array}$ & $\begin{array}{l}33 \\
67\end{array}$ & $\begin{array}{l}38 \\
62\end{array}$ \\
\hline \multicolumn{3}{|l|}{ Units produced per day } \\
\hline $\begin{array}{l}<500 \\
500-1000 \\
>1000\end{array}$ & $\begin{array}{l}41 \\
31 \\
28\end{array}$ & $\begin{array}{r}68 \\
27 \\
5\end{array}$ \\
\hline \multicolumn{3}{|c|}{ Adjustment of workplace by a professional } \\
\hline $\begin{array}{l}\text { Yes } \\
\text { No }\end{array}$ & $\begin{array}{l}66 \\
34\end{array}$ & $\begin{array}{l}84 \\
16\end{array}$ \\
\hline
\end{tabular}

ferred to as the "other employment" group. The rest were unemployed (participating in educational activities, on sick leave, on maternity leave, retired, or otherwise out of employment). Since this unemployed group was rather diverse and each subgroup was small, data from this group have only been included when relevant. Dividing the study group in 1991 into age groups showed that, among those 35 years of age or below, $77 \%$ had left their sewing job during the six-year period, while this was true for only $57 \%$ of those above 35 years of age. This finding agrees with the fact that, in 1991, the mean age was much higher for the sewing machine operators, 40 (range 24-65) years, than for the "other employment" group, 32 (range 24-62) years. Furthermore, the employment time as a sewing machine operator was 9.0 (range $0.3-35.0$ ) years in 1985 and 15.3 (range 2.944.0) years in 1991 in the sewing machine operator group, while in the "other employment" group, it was only 3.1 (range $0.1-28.0$ ) years in 1985 and 5.3 (range $0.3-28.0$ ) years in 1991. As a reason for leaving their job as a sewing machine operator, $21 \%$ reported that they did so only because the factory was closed down. However, $20 \%$ reported musculoskeletal symptoms as the only reason, $39 \%$ reported various other reasons, and $20 \%$ stated multiple reasons. In the last group, $13 \%$ reported musculoskeletal symptoms as one of the reasons; therefore altogether $33 \%$ reported musculoskeletal symptoms as one reason for leaving their job as a sewing machine operator.

\section{Exposure}

Exposure was assessed by questions regarding the type of machine operated, work organization, workplace design, units produced per day, and payment system. Piecework was graded by the employer according to the number of units finished a day relative to a standard number, which was referred to as efficiency 100 . Exposure time was defined as time of employment as a sewing machine operator. Factories with manual transport systems and no automatic sewing units were classified as low-level technology, those with manual transport systems and automatic sewing units were considered as mid-level technology, and those with automatic transport systems and automatic sewing units fell into the category of high-level technology. In table 1, the percentage distribution is given for the different exposure types.

The exposure variables given in table 1 , age, employment time, and employment status were used as independent variables in the analysis of the cross-section in 1985. Only a few of these variables were important in the analysis of the development or improvement of symptoms during the follow-up. They were age, employment time as a sewing machine operator, and employment 
status in 1991. Those who were operators in 1991 were considered exposed in the follow-up, whereas those who had changed occupation (the "other employment" group) were considered unexposed. In the analysis of getting another job in 1991, being symptomatic in 1991 was treated as an independent variable.

\section{Outcome}

Musculoskeletal symptoms (ache, pain, discomfort) were assessed with the standardized Nordic questionnaire (20). Several outcomes were analyzed as defined directly by the Nordic questionnaire, for example, the 7-day and 12month prevalences, the restriction of activities in work and leisure time, and treatment. Further outcomes were analyzed, as defined from information from the Nordic questionnaire. The development of 7-day symptoms was defined as not having had symptoms during the last 7 days in 1985 and having had symptoms during the last 7 days in 1991. Likewise, the development of 12-month symptoms was defined as not having had symptoms during the last 12 months in 1985 and having had symptoms in 1991. Finally, developing long-lasting symptoms was defined as having less than 30 days with symptoms in 1985 and more than 30 days with symptoms in 1991.

Improvement of 7 days, 12 months, and long-lasting symptoms was defined as the opposite of the development of symptoms (ie, as having symptoms in 1985 and having no symptoms (for long-lasting: less than 30 days) in 1991. Finally, in one analysis, leaving sewing work and getting another job in 1991 was treated as an outcome.

\section{Statistics}

The follow-up part of the study was analyzed by means of the following tabulations: (i) prevalences in 1985 and 1991, significance being tested with the chi-square test; (ii) number of persons reporting differently on the two occasions, significance being tested with McNemar's test; (iii) persons at risk for given outcomes (eg, persons without neck symptoms in 1985 being defined as at risk of developing symptoms in 1991). Risk factors for this outcome were measured as odds ratios (OR) and estimated with logistic regression with the probit procedure of the SAS (statistical analysis system) program. Due to the low number of potential explanatory variables, the model building process was simple. If the variables were significant when alone in the model, they were included in the final model. Since the material was small and correlations existed between age, employment time, and employment status, the variables usually became nonsignificant when the others were entered. The variables were kept in the model even though they were no longer significant to assure less biased estimates than with reports of the bivariate results. The bivariate analyses are referred to in the text as unadjusted. In the model for the disappearance of long-lasting neck symptoms, age and employment time were not significant when entered as single variables. When they were forced into the model, they changed the estimate for employment status less than $5 \%$. Therefore, they were omitted from the final model. The significance of the variables in the models was assessed with the likelihood ratio test (21). The level of significance was 0.05 .

\section{Results}

\section{Exposure}

Only small changes occurred in the exposure from 1985 to 1991 (table 1). The majority worked full-time, was paid by unit, and used either lockstitchers or overlockers. Most of the operators worked at only one machine, and few left the sewing machine to collect or deliver materials. In 1991, more operators received professional assistance for individual adjustment of their chair and table height, the number of units made per day had decreased, and a smaller number had an efficiency rating above 125 .

\section{Musculoskeletal symptoms in the cross-sections}

For all the body regions, the 12-month and 7-day prevalences for musculoskeletal symptoms are presented in table 2. Musculoskeletal symptoms of the neck, shoulders, upper back, lower back, and hands were the most frequent. For the group of operators who remained operators throughout the study period no significant changes were found in the prevalences of symptoms from 1985 to 1991. In contrast, for the "other employment" group, the prevalence of symptoms decreased significantly for the neck, shoulders, upper back, and lower back. The unemployed group was not homogeneous, and therefore was not tested for significant differences. The prevalence of the long-lasting symptoms also remained unchanged in the operator group, whereas a significant decrease was seen in the neck and shoulder symptoms in the "other employment" group from 1985 to 1991 (table 3). In the "other employment" group, there was a tendency towards higher symptom prevalences for the neck, shoulders and upper back in 1985 compared with the group continuing as sewing machine operators. In 1991, the situation had reversed (tables 2 and 3 ).

A larger percentage of the operators was unable to carry out normal work (at home or away from home) for more than 1 day because of neck or shoulder symptoms in 1991 than in 1985 (table 3) (a nonsignificant finding). Furthermore, neck and shoulder symptoms caused 8 $17 \%$ of the operators to decrease their activity during work or leisure time in 1985 and 1991. In contrast, for the "other employment" group, the results indicated that the prevalences for not always being able to carry out 
Table 2. Prevalences of the 12-month and 7-day musculoskeletal symptoms among the total group in 1985 and the two groups "sewing machine operator" and "other employment" in 1985 and 1991.

\begin{tabular}{|c|c|c|c|c|c|c|c|}
\hline \multirow[t]{2}{*}{ Symptoms } & \multirow{2}{*}{$\begin{array}{c}\begin{array}{c}\text { Total group } \\
\text { in } 1985 \\
(\mathrm{~N}=303)\end{array} \\
1985\end{array}$} & \multicolumn{2}{|c|}{$\begin{array}{l}\text { Sewing machine operator } \\
\text { in } 1991 \\
(N=77)\end{array}$} & \multicolumn{2}{|c|}{$\begin{array}{l}\text { Other employment in } 1991 \\
\qquad(N=82)\end{array}$} & \multicolumn{2}{|c|}{$\begin{array}{l}\text { Unemployed in } 1991 \\
\qquad(N=82)\end{array}$} \\
\hline & & 1985 & 1991 & 1985 & 1991 & 1985 & 1991 \\
\hline \multicolumn{8}{|l|}{ Last 12 months } \\
\hline $\begin{array}{l}\text { Neck } \\
\text { Shoulders } \\
\text { Elbows } \\
\text { Wrists and hands } \\
\text { Upper back } \\
\text { Low back } \\
\text { Hips } \\
\text { Knees } \\
\text { Ankles or feet }\end{array}$ & $\begin{array}{r}56 \\
54 \\
7 \\
32 \\
33 \\
45 \\
11 \\
16 \\
16\end{array}$ & $\begin{array}{r}57 \\
53 \\
7 \\
28 \\
24 \\
38 \\
12 \\
16 \\
12\end{array}$ & $\begin{array}{r}55 \\
51 \\
7 \\
26 \\
35 \\
47 \\
14 \\
22 \\
9\end{array}$ & $\begin{array}{r}66 \\
59 \\
5 \\
32 \\
41 \\
53 \\
12 \\
13 \\
8\end{array}$ & $\begin{array}{r}40 \\
44 \\
7 \\
26 \\
18 \\
45 \\
17 \\
10 \\
5\end{array}$ & $\begin{array}{l}54 \\
52 \\
10 \\
37 \\
33 \\
49 \\
14 \\
18 \\
24\end{array}$ & $\begin{array}{l}48 \\
43 \\
20 \\
31 \\
35 \\
57 \\
32 \\
32 \\
19\end{array}$ \\
\hline \multicolumn{8}{|l|}{ Last 7 days } \\
\hline $\begin{array}{l}\text { Neck } \\
\text { Shoulders } \\
\text { Elbows } \\
\text { Wrists and hands } \\
\text { Upper back } \\
\text { Low back } \\
\text { Hips } \\
\text { Knees } \\
\text { Ankles or feet }\end{array}$ & $\begin{array}{r}32 \\
28 \\
5 \\
15 \\
18 \\
25 \\
6 \\
9 \\
8\end{array}$ & $\begin{array}{r}30 \\
32 \\
5 \\
11 \\
11 \\
23 \\
7 \\
12 \\
7\end{array}$ & $\begin{array}{r}37 \\
32 \\
5 \\
13 \\
22 \\
25 \\
10 \\
11 \\
3\end{array}$ & $\begin{array}{r}45 \\
33 \\
3 \\
17 \\
22 \\
28 \\
6 \\
4 \\
4\end{array}$ & $\begin{array}{r}23 \\
23 \\
5 \\
12 \\
10 \\
15 \\
10 \\
5 \\
2\end{array}$ & $\begin{array}{r}23 \\
27 \\
6 \\
19 \\
20 \\
24 \\
4 \\
9 \\
8\end{array}$ & $\begin{array}{l}26 \\
27 \\
11 \\
20 \\
24 \\
35 \\
23 \\
20 \\
11\end{array}$ \\
\hline
\end{tabular}

Table 3. Prevalences of the symptoms for more than 30 days during the last 12 months (ie, long-lasting symptoms) and responses to the question "What is the total length of time that neck or shoulder trouble has prevented you from doing your normal work (at home or away from home) during the last 12 months?"

\begin{tabular}{|c|c|c|c|c|c|}
\hline \multirow[b]{3}{*}{$\begin{array}{l}\text { Symptoms for more tha } \\
30 \text { days }\end{array}$} & \multirow{2}{*}{$\begin{array}{c}\begin{array}{c}\text { Total } \\
\text { group } \\
\text { in 1985 } \\
(\mathrm{N}=303)\end{array} \\
1985\end{array}$} & \multicolumn{2}{|c|}{$\begin{array}{c}\text { Sewing machine } \\
\text { operator } \\
\text { in 1991 } \\
(N=77)\end{array}$} & \multicolumn{2}{|c|}{$\begin{array}{c}\text { Other } \\
\text { employment } \\
\text { in } 1991 \\
(N=82)\end{array}$} \\
\hline & & 1985 & 1991 & 1985 & 1991 \\
\hline & & & & & \\
\hline $\begin{array}{l}\text { Neck } \\
\text { Shoulders }\end{array}$ & $\begin{array}{l}35 \\
34\end{array}$ & $\begin{array}{l}34 \\
31\end{array}$ & $\begin{array}{l}33 \\
29\end{array}$ & $\begin{array}{l}44 \\
43\end{array}$ & $\begin{array}{l}18 \\
17\end{array}$ \\
\hline $\begin{array}{l}\text { Unable to carr } \\
\text { normal work } \\
\text { than } 1 \text { day }\end{array}$ & & & & & \\
\hline $\begin{array}{l}\text { Neck } \\
\text { Shoulders }\end{array}$ & $\begin{array}{r}10 \\
9\end{array}$ & $\begin{array}{l}5 \\
3\end{array}$ & $\begin{array}{l}16 \\
11\end{array}$ & $\begin{array}{l}16 \\
12\end{array}$ & $\begin{array}{l}10 \\
10\end{array}$ \\
\hline
\end{tabular}

normal work (at home or away from home) or having decreased activity during the last 12 months in 1991 had decreased, although this could not be significantly proved.

In 1985 , a total of $15 \%$ had consulted a physician, physiotherapist, chiropractor, or other health care professional because of neck symptoms, and in 1991 approximately $20 \%$ reported a similar situation in both groups during the last 12 months. The numbers were roughly the same for shoulder pain.

\section{Exposure versus musculoskeletal symptoms of the neck and shoulders}

In 1985, the 12-month and 7-day symptoms from the neck and shoulders tended to be related to high efficien- cy although this relationship was not statistically significant. The prevalences of the 12-month neck symptoms were 36,53 , and $61 \%$ for the efficiency groups $<100$, $100-125$ and $>125$, respectively. The 12 -month prevalence of neck symptoms was of the same order of magnitude in the group paid by hourly wage (63\%) as for the high-efficiency group. The operators who always worked at the same machines compared with those working at different machines only showed significantly higher daily neck symptoms, 13 and $2 \%$, respectively. The same tendency was seen for shoulder symptoms. Furthermore, workers who collected or delivered their own materials had a significantly lower 7-day prevalence of shoulder symptoms than the rest (18\% for this group compared with $33 \%$ for the rest). Musculoskeletal symptoms were not significantly related to the level of technology or individual adjustment of the table and chair.

\section{Appearance and disappearance of neck and shoulder symptoms}

Even though the 12-month and 7-day prevalences of symptoms remained unchanged for the operator group from 1985 to 1991, numerous operators reported different symptom statuses in the two questionnaires (figure 1). Concerning neck symptoms during the last 12 months, $40 \%$ of the operator group responded positively and $29 \%$ responded negatively in 1985 and 1991, respectively, while $31 \%$ changed their responses (for $16 \%$ the symptoms disappeared and for $15 \%$ the symptoms appeared). In the "other employment" group, 29\% gave a positive answer and $21 \%$ gave a negative answer both in 1985 and 1991. As many as 50\% changed their response, $38 \%$ reported the neck symptoms as having disappeared 
and $13 \%$ that the symptoms appeared during the last 12 months. For shoulder symptoms, values of the same magnitude were registered. For the 7-day and long-lasting symptoms categories, the changes from 1985 to 1991 followed the same pattern. The unadjusted odds ratios for developing neck symptoms in 1991 among the operators compared with the "other employment" group were 0.85 (95\% CI $0.29-2.46,12$-month symptoms) and 1.43 (95\% CI 0.55-3.71, 7-day symptoms). The unadjusted odds ratio for developing shoulder symptoms in 1991 among the operators, compared with the "other employment" group, was 0.88 (95\% CI 0.33-2.37, 12-month symptoms) and 1.22 (95\% CI 0.44-3.40, 7-day symptoms). For the development of long lasting symptoms, the operators had an odds ratio of $1.46(95 \%$ CI 0.53 3.99 ) for the neck and 0.88 (95\% CI $0.28-2.75$ ) for the shoulders when compared with the "other employment" group. Likewise, no relation was found between age or employment time as an operator and the risk of developing long-lasting symptoms. In short, the analysis did not show the development of neck or shoulder symptoms among workers who had worked as a sewing machine operator to be significantly related to exposure, exposure time, or age.

A different data analysis was used to evaluate the improvement from 1985 to 1991 . For the neck symptoms, a significantly higher risk of improvement was found in the "other employment" group when compared with the operator group, unadjusted odds ratio $3.26(95 \%$ Cl 1.38-7.72, 12-month symptoms) and 3.90 (95\% CI 1.28 - 11.92, 7-day symptoms). A nonsignificantly higher improvement was found for shoulder symptoms, unadjusted odds ratio 1.50 (95\% CI $0.50-4.46$, 12month symptoms) and 2.66 (95\% CI $0.84-8.46,7$-day symptoms). The strongest indicator of improvement of long-lasting symptoms was "other employment" (table 4). Furthermore high age and high seniority as in operator were negatively associated with the disappearance of long-lasting shoulder symptoms.

\section{Employment time and age versus musculoskeletal symptoms in the neck and shoulders}

In the 1985 data, no association between long-lasting neck or shoulder symptoms and age or employment time as a sewing machine operator was found. In contrast, in the total data material from 241 persons in 1991, we found rather pronounced associations between longlasting neck and shoulder symptoms and employment time (table 5). Rather strong predictors for leaving the job as a sewing machine operator and obtaining another job were (i) being symptomatic, (ii) young age, and (iii) low employment time as a sewing machine operator (table 6). Evidently, the association between employment time and symptoms developed from 1985 to 1991 was

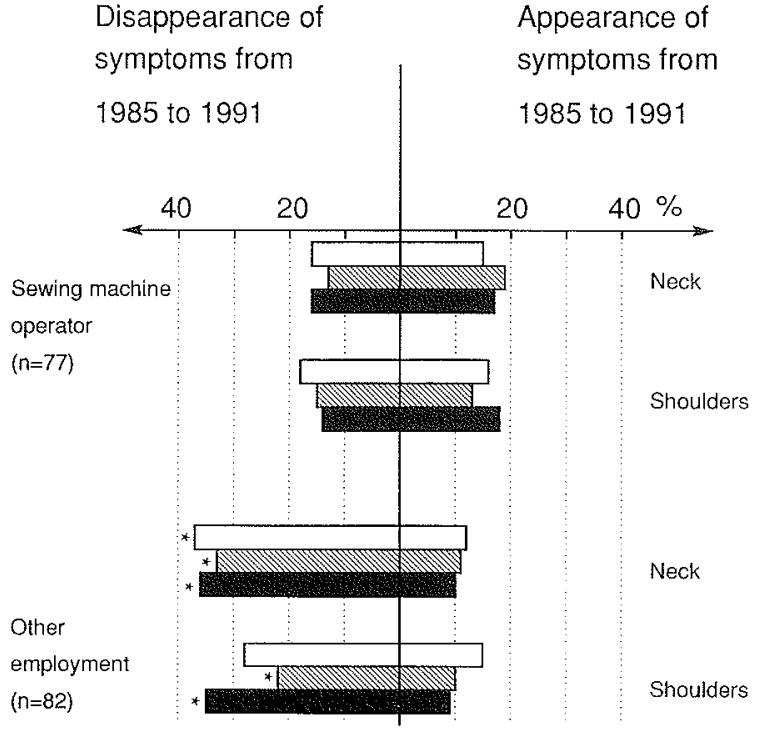

Figure 1. Changes in symptom status from 1985 to 1991. [open bars = 12-month symptoms, hatched bar $=7$-day symptoms, blackbar $=$ longlasting symptoms, ${ }^{*}=$ disappearance of symptoms significantly higher than the appearance of symptoms (McNemar's test)]

Table 4. Risk factors for improvement in long-lasting neck or shoulder symptoms in the two groups "sewing machine operator" and "other employment." (OR = odds ratio, $95 \% \mathrm{Cl}=95 \%$ confidence interval)

\begin{tabular}{llc}
\hline Disappearance of long lasting symptoms & OR & $95 \% \mathrm{Cl}$ \\
\hline Neck & & \\
Employment status & & \\
in 1991 & & \\
$\quad$ Sewing machine & & - \\
operator & & \\
Other employment & 4.50 & $1.37-14.83$ \\
Shoulders & & \\
Employment status & & \\
in 1991 & & \\
$\quad$ Sewing machine & & \\
operator & 1 & - \\
Other employment & 3.46 & $0.87-13.79$ \\
Age in 1991 & & \\
$\quad \leq 35$ years & 1 & - \\
$\quad>35$ years & 0.63 & $0.11-3.48$ \\
Employment time as a & & \\
sewing machine operator & & \\
in 1985 & & \\
$\quad<4$ years & & \\
$4-7$ years & 1 & - \\
$\geq 8$ years & 0.55 & $0.09-3.20$ \\
\hline
\end{tabular}

due to the disappearance of symptoms among the young persons who left sewing work between 1985 and 1991.

\section{Discussion}

In this study high prevalences of neck and shoulder symptoms were found among the sewing machine opera- 
Table 5. Relation between employment time as a sewing machine operator and long-lasting neck and shoulder symptoms in the whole material in 1991. (OR = odds ratio, $95 \% \mathrm{Cl}=$ confidence interval)

\begin{tabular}{lcc}
\hline $\begin{array}{l}\text { Employment time as a } \\
\text { sewing machine operator }\end{array}$ & OR & $95 \% \mathrm{Cl}$ \\
\hline < 8years & & \\
$\quad$ Neck symptoms in 1991 & 1 & - \\
$\quad$ Shoulder symptoms in 1991 & 1 & - \\
$8-14$ years & & \\
$\quad$ Neck symptoms in 1991 & 1.07 & $0.44-2.63$ \\
Shoulder symptoms in 1991 & 1.27 & $0.47-3.40$ \\
$\geq 15$ years & & \\
$\quad$ Neck symptoms 1991 & 2.08 & $0.77-5.61$ \\
Shoulder symptoms 1991 & 4.28 & $1.47-12.49$ \\
\hline
\end{tabular}

Table 6. Predictors in the two groups "sewing machine operator" and "other employment" for having employment other than sewing machine operator in $1991 .(0 \mathrm{R}=$ odds ratio, $95 \%$ $\mathrm{Cl}=95 \%$ confidence interval)

\begin{tabular}{llc}
\hline Predictor & OR & $95 \% \mathrm{Cl}$ \\
\hline Having had long lasting neck symptoms & & \\
and long lasting shoulder symptoms & & \\
in 1985 & & \\
No & 1 & - \\
Yes & 2.66 & $1.05-6.76$ \\
Age in 1991 & & \\
< 30 years & 1 & - \\
$30-39$ years & 0.78 & $0.31-1.93$ \\
$\geq 40$ years & 0.26 & $0.09-0.77$ \\
Employment time as a sewing machine & & \\
operator in 1985 & & \\
<4 years & 1 & \\
$4-7$ years & 0.43 & $0.16-1.19$ \\
$8-14$ years & 0.47 & $0.15-1.45$ \\
$\geq 15$ years & 0.07 & $0.01-0.63$ \\
\hline
\end{tabular}

tors, in congruence with the results of many studies among workers performing repetitive or sustained static work with their arms and hands $(1-6)$. Of special note are the high 7-day prevalences of symptoms of the neck, shoulders, and upper back among the operators $(37,32$, and $22 \%$, respectively) compared with those found among a mixed group of Danish female workers $(23,23$, and $11 \%$, respectively) $(22,23)$, whereas the prevalences for the other body regions were of the same magnitude for the two groups. Concerning the prevalence of longlasting neck and shoulder symptoms among the operators in 1985 and 1991, our results (about 35\%) are higher than the prevalences of chronic pain (about $25 \%$ ) reported by Andersen \& Gaardboe among present and former operators (16). They defined chronic pain as pain reported for a total of more than 30 days during the last 12 months, in combination with having experienced continuous pain for a month or more in any period after having started their work career. Only the first part of the definition corresponds to our definition for long-lasting symptoms and this difference may account for higher prevalences. Punnett et al (5) defined persistent pain as pain which lasted for most days during one month or more within the past year and found $20 \%$ of the garment workers having persistent shoulder pain.

An interesting question is to what extent the perceived symptoms according to the questionnaire are chronic clinical manifest disorders. A Swedish investigation has shown failly good agreement between information obtained by this questionnaire on 7-day prevalences of neck and shoulder symptoms and a clinical examination (24). However, regarding chronicity, we have shown that many workers changed symptom status from 1985 to 1991, and for many workers the symptoms disappeared during the follow-up period, especially among those who quit sewing work. This was also the case for the long-lasting symptoms, a fact which implies that most of the symptoms, although long-lasting, were not truly chronic (ie, permanent). In historical cohort studies the prevalence of chronic symptoms has been used as a measure of cases occurring throughout the exposure period $(16,18)$. The implicit argument underlying the method is that, if an outcome is chronic, it can be ascertained by just one (cross-sectional) data collection, which will identify the cases arisen throughout the follow-up period. Although incidence rates cannot be calculated when the time of onset of the disease is unknown, the prevalence proportion can be interpreted as the cumulative incidence (ie, the risk) under the assumption of chronicity. This finding shows that rigorous criteria for chronicity should be used in such studies, since severe bias can be introduced into risk estimates related to cumulative exposure measures such as employment time if the outcome is not truly chronic (table 4). In the present study the outcome defined as long-lasting symptoms according to the Nordic questionnaire proved not to be truly chronic. If some persons develop truly chronic symptoms due to repetitive work, one would expect the symptoms to be found among sewing machine operators with high seniority and symptoms. Only a few of these persons were present for the follow up study; thus the absence of significant findings regarding this aspect should not be interpreted as a negative finding but as a noninformative one. The literature is inconsistent concerning the relationship between age or years of employment as a sewing machine operator and the prevalence of symptoms of the neck and shoulders, some finding correlations $(1-4,16)$ and others not $(5,18,25)$.

One reason for not finding an increase in symptoms among sewing machine operators from 1985 to 1991 may be that the nature of the work had changed towards decreasing the risk factors. For instance, the decreased number of units produced per day, the decrease in the number of operators working with an efficiency rate greater than 125, and the decrease in work per week 
(40 to $37 \mathrm{~h}$ according to legislation) are all changes which may lead to a decrease in the prevalence of symptoms. This finding agrees with other findings of a positive correlation between, for example, diagnosed tension neck symptoms and workhours per week (2). Furthermore, the "healthy worker effect" could account for this finding, since the group changing to another job had a higher prevalence of disorders in 1985 than those remaining as sewing machine operators.

During the six-year study period, about two-thirds of the operators left sewing work, and among these persons $33 \%$ reported musculoskeletal disorders as a reason, a finding which agrees with that of other studies. In a Swedish investigation of sewing machine operators $66 \%$ left their job during a three-year period and $17 \%$ stated that neck or shoulder problems were the main or contributory reason (2). Furthermore, in an investigation among female assembly workers, $26 \%$ left the job because of pain in the musculoskeletal system (4).

Repetitive precision work, such as operating sewing machines, imposes a sustained high static load on shoulder muscles (6). The static load was monitored using electromyography (EMG) and amounted to around $10 \%$ of the maximal muscle strength in a workplace study including 30 operators representatively selected among those participating in the present questionnaire study in 1985 (26). EMG signs of muscle fatigue were also found during the workday. The significant decrease in symptoms from the neck, shoulder, and upper back in the "other employment" group was likely to have been caused by a change in the load on the neck and shoulder muscles, since the development of symptoms from all other parts of the body were independent of their employment in 1991. Judged by the job title, some of the workers in the "other employment" group also performed repetitive tasks, but the exposures in these jobs were not ascertained in the questionnaire, and they may have at least to some extent caused a significant change in the muscle load pattern. However, some misclassification is likely to have occurred when this group was considered unexposed with respect to repetitive work in 1991, and this possibility may explain the lack of significance for some of the analysis between the exposed and unexposed persons. Findings of Jonsson and his co-workers (14) support our results concerning the possibility of a job change influencing neck and shoulder symptoms. In a two-year follow-up study of female workers in the electronics industry, about $50 \%$ of the workers changed to a nonrepetitive job after one year. The strongest predictor for improvements in neck and shoulder symptoms duting the second year was allocation to a more varied work task.

Job rotation is a widely recommended form of intervention for introducing variation into repetitive and monotonous muscular work. From the present results it can be seen that the problems cannot be solved by changing from one sewing machine to another, probably because it hardly gives any variation in the work pattern. Since the sustained static load is an important risk factor for developing neck and shoulder symptoms, there is an urgent need to reduce the time with this load component. Kamwendo et al (3) found a higher prevalence of shoulder symptoms when medical secretaries worked more than $5 \mathrm{~h}$ a day with an office machine. In the present study, collecting and delivering one's own materials did not reduce the prevalence of symptoms very much although it created a break with dynamic work, but the time spent with these tasks was short compared with the daily hours of sewing work. Therefore, to obtain real changes in work posture and work mode, the complete work process must be reorganized so that the time spent at the sewing machine by each operator decreases and the time spent performing other tasks where the whole body is used in a dynamic way increases.

In conclusion, sewing machine operators suffer from high prevalences of neck and shoulder symptoms. Although long-lasting, these symptoms may disappear after a change in occupation. This is true especially for young sewing machine operators with short seniority. The findings strongly support further attempts to reorganize repetitive work into a more varied work pattern.

\section{References}

1. Björkstén $M G$, Jonsson $B$. Besvär från rörelsesorganen bland läkarsekreterare [Musculoskeletal symptoms among medical secretaries]. Stockholm: Arbetarskyddsverket, 1987:1-40. Arbete och hälsa 34 .

2. Blåder S, Barck-Holst U, Danielsson S, Ferhm E, Kalpamaa M, Leijon $M$, et al. Neck and shoulder complaints among sewing-machine operators: a study concerning frequency, symptomatology and dysfunction. Appl Ergon 1991;22(4): $251-7$.

3. Kamwendo K, Linton SJ, Moritz U. Neck and shoulder disorders in medical secretaries, part I: pain prevalence and risk factors. Scand J Rehabil Med 1991;23:127-33.

4. Ohlsson K, Attewell R, Skerfving S. Self-reported symptoms in the neck and upper limbs of female assembly workers. Scand J Work Environ Health 1989;15(1):75-80.

5. Punnett L, Robins JM, Wegman DH, Keyserling WM. Soft tissue disorders in the upper limbs of female garment workers. Scand J Work Environ Health 1985;1 1(6):417-25.

6. Vihma T, Nurminen M, Mutanen P. Sewing-machine operators' work and musculoskeletal complaints. Ergonomics 1982; 25(4):295-8.

7. Hagberg M, Wegman DH. Prevalence rates and odds ratios of shoulder-neck diseases in different occupational groups. Br J Ind Med 1987:44(9):602-10.

8. Armstrong TJ, Buckle P, Fine LJ, Hagberg M, Jonsson B, Kilbom $\AA$, et al. A conceptual model for work-related neck and upper-limb musculoskeletal disorders. Scand J Work Environ Health $1993 ; 19(2): 73--84$. 
9. Hagberg M, Kilbom Å, Buckle P, Fine LJ, Itani T, Läubli T, et al. Strategies for prevention of work related musculoskeletal disorders: consensus paper. Int J Ind Ergon 1993;11:77—81.

10. Feuerstein M, Callan-Harris S, Hickey P, Dyer D, Armbruster W, Carosella AM. Multidisciplinary rehabilitation of chronic work-related upper extremity disorders. J Occup Med 1993; 35(4):396-403

11. Sommerich CM, McGlothlin JD, Marras WS. Occupational risk factors associated with soft tissue disorders of the shoulder: a review of recent investigations in the literature. Ergonomics 1993;36(6):697-717.

12. Winkel J, Westgaard R. Occupational and individual risk factors for shoulder-neck complaints, part I: guidelines for the practitioner. Int J Ind Ergon 1992; 10:79 - 83.

13. Winkel J, Westgaard R. Occupational and individual risk factors for shoulder-neck complaints, part II: the scientific basis (literature review) for the guide. Int J Ind Ergon 1992;10:85104.

14. Jonsson BG, Persson J, Kilbom $\AA$. Disorders of the cervicobrachial region among female workers in the electronics industry: a two-year follow up. Int J Ind Ergon 1988;3:1-12.

15. Hägg GM, Suurküla J, Kilbom Å. Prediktorer för belastningsbesvär i skuldra/nacke: en longitudinell studie på kvinnliga montörer [Predictors for work related shoulder/neck disorders: a longitudinal study of female assembly workers]. Stockholm: Arvetarskyddsverket, 1990:1—78. Arbete och Hälsa 10.

16. Andersen $\mathrm{JH}$, Gaardboe O. Prevalence of persistent neck and upper limb pain in a historical cohort of sewing machine operators. Am J Ind Med 1993;24:677—87.

17. Andersen JH, Gaardboe O. Musculoskeletal disorders of the neck and upper limb among sewing machine operators: a clinical investigation. Am J Ind Med 1993;24:689-700.

18. Brisson C, Vinet A, Vézina $M$, Gingras $S$. Effect of duration of employment in piecework on severe disability among female garment workers. Scand J Work Environ Health 1989;
15(5):329-34.

19. Sjøgaard G, Ekner D, Schibye B, Simonsen EB, Jensen BR, Christiansen JU, et al. Skulder/nakke-besvær hos syersker: en epidemiologisk og arbejdsfysiologisk undersøgelse [Neck and shoulder symptoms among sewing machine operators, an epidemiological and work physiological study]. Copenhagen: Arbejdsmiljøfondet, 1987.

20. Kuorinka I, Jonsson B, Kilbom $\AA$, Vinterberg H, BieringSørensen F, Andersson G, et al. Standardised Nordic questionnaires for the analysis of musculoskeletal symptoms. Appl Ergon 1987;18(3):233-7.

21. Hosmer DW, Lemeshow S. Applied logistic regression. New York (NY): John Wiley \& Sons, Inc, 1989:32.

22. Nord-Larsen M, Ørhede E, Nielsen J, Burr H. Lønmodtagernes arbejdsmiljø 1990, bind 1: sammenhænge mellem arbejdsmilj $\varnothing$ og helbred [Work environment and health in Danish employees 1990, volume 1]. Copenhagen: Arbejdsmiljøfondet, 1992.

23. Ørhede E, Nord-Larsen M, Burr H, Nielsen J. Lønmodtagernes arbejdsmiljø 1990, bind 2: kortlægning af påvirkninger, arbejdsprocesser og helbred [Work environment and health in Danish employees 1990, volume 2]. Copenhagen: Arbejdsmiljøfondet, 1992.

24. Ohlsson K, Attewell RG, Johnsson B, Ahlm A, Skerfving S. An assessment of neck and upper extremity disorders by questionnaire and clinical examination. Ergonomics 1994;37(5): 891-7.

25. Kuorinka I, Koskinen P. Occupational rheumatic diseases and upper limb strain in manual jobs in a light mechanical industry. Scand J Work Environ Health 1979;5 Suppl 3:39-47.

26. Jensen BR, Schibye B, Søgaard K, Simonsen EB, Sjøgaard G. Shoulder muscle load and muscle fatigue among industrial sewing-machine operators. Eur J Appl Physiol 1993;67:46775 .

Received for publication: 16 September 1994 